\title{
PERILAKU MEMAAFKAN PADA ANAK DENGAN CONDUCT DISORDER
}

\author{
Resnia Novitasari \\ Fakultas Psikologi dan Ilmu Sosial Budaya Universitas Islam Indonesia \\ Amitya Kumara \\ Fakultas Psikologi Universitas Gadjah Mada
}

\begin{abstract}
This research was aimed to explore the behavior changes, especially the forgiving behavior in children with conduct disorder. It was assumed that forgiving behavior played as predisposition in reducing destructive behavior. A training module was created and implemented to facilitate the occurrence of behavioral changes. Data was collected using Triangulation method and then analyzed with successive approximation (Neuman, 2000). There are significant changes in most of the respondents in understanding and re-experiencing the targeted behavior even though the mode of changes was vary for each subject. Forgiving behavior in children with conduct disorder would emerge after expressing the same destructive behavior that other did to the respondent and with full support from peers.
\end{abstract}

Keywords: Children with conduct disorder, forgiving behavior

Masa kanak-kanak merupakan masa yang merupakan tahapan penting dalam perkembangan setiap individu. Di dalam perkembangannya, individu diharapkan tumbuh dan berkembang secara matang dalam berbagai aspek kehidupan baik fisik, psikis, sosial, maupun spiritual. Dengan demikian, setiap generasi penerus dapat diharapkan mencapai kematangan secara optimal dan berfungsi sebagai peletak dasar bagi kemajuan pribadi.

Namun demikian, terdapat beberapa hal yang dapat menghambat optimalisasi pertumbuhan tersebut. Beberapa gangguan perkembangan tersebut dapat berasal dari dalam maupun dari luar diri anak. Salah satu gangguan yang terdapat pada diri anak adalah conduct disorder. Conduct disorder dapat diartikan sebagai suatu gangguan perilaku yang termasuk dalam perilaku antisosial yang seringkali ditandai dengan perilaku menyakiti orang lain. Walaupun demikian, perilaku yang muncul lebih tereksternalisasi dan dibedakan dari perilaku menyakiti diri sendiri (Dodge \& Pettit, 2003). Conduct disorder dalam DSM IV memiliki beberapa gejala antara lain sering mengintimidasi orang lain, memulai perkelahian yang mengakibatkan cedera fisik, menyakiti orang lain maupun hewan, serta tindakan yang melanggar aturan baik di institusi pendidikan, sosial, maupun hukum (Wenar, 1994).

Gangguan perilaku ini memiliki berbagai dampak yang merugikan bagi anak yang dapat menghambat perkembangan di masa selanjutnya. Dampak yang ditimbulkan dari conduct disorder antara lain adanya kesulitan untuk mempertahankan pola interaksi hubungan dengan teman sebaya, kurang mampu menyesuaikan diri dengan lingkungan sekitarnya, kecenderungan untuk 
sekitarnya, kecenderungan untuk berhenti sekolah (school drop out), serta munculnya perilaku antisosial pada masa remaja maupun sesudahnya (Cairns, Cairns \& Neckerman, 1989; Campbell \& Ewing, 1990; Ladd \& Price, 1987; Parker \& Asher, 1987; Pope, Bierman, \& Mumma, 1991; Taylor, 1989; dalam Stormshak \& WebsterStratton, 1999).

Dalam permasalahan tersebut, dapat dilihat bahwa anak dengan conduct disorder kurang memiliki kemampuan yang positif untuk dapat memberikan kepedulian terhadap orang lain. Oleh sebab itu, dibutuhkan pembentukan sikap lebih peduli kepada orang lain yang berfungsi sebagai faktor protektif yang bersifat eksternal. Sikap untuk mampu berempati terhadap orang lain dapat mencegah tindakan yang agresif terhadap orang lain dan lebih mampu merasakan apa yang dirasakan orang lain (Hastings, Zahn-Waxler, Usher, Robinson, \& Bridges, 2000).

Salah satu bentuk dan manifestasi dari kepedulian terhadap orang lain adalah perilaku memaafkan. Perilaku memaafkan sendiri merupakan suatu bentuk akomodasi konflik yang berupa keinginan untuk menghambat timbulnya perilaku destruktif dan menyakiti orang lain yang kemudian digantikan oleh keinginan untuk berperilaku secara lebih konstruktif (McCullough, Rachal, \& Worthington, 1997).Perilaku memaafkan ini dapat dikembangkan oleh setiap individu mulai dari anak hingga dewasa. Kelebihan dari memaafkan bagi individu menurut Enright (2001) antara lain adalah memberikan kesehatan baik fisik maupun psikis, memperbaiki hubungan dan memberi perhatian terhadap kesejahteraan orang lain, serta merupakan suatu bentuk tindak moralitas.

Responden penelitian ini adalah anak berusia 9-12 tahun. Pada usia tersebut anak telah mulai mengembangkan kepekaan terhadap teman sebaya dan menjalin hubungan yang lebih positif (Hetherington, Locke, \& Parke, 1999). Diharapkan melalui masa peka tersebut, perilaku memaafkan menjadi salah satu upaya untuk dapat meminimalkan perilaku destruktif pada anak dengan conduct disorder.

\section{METODE PENELITIAN}

\section{Responden}

Jumlah responden pada penelitian ini sebanyak 3 orang anak berusia antara 9-12 tahun dan semuanya berjenis kelamin lakilaki. Ketiga anak tersebut memiliki karakteristik anak conduct disorder dengan tipe undersocialized conduct disorder dan solitary aggressive type. Selain itu, responden mendapatkan izin dari orangtua atau walinya untuk menjadi subjek dalam penelitian ini dan mengikuti pelatihan selama dua hari. Kriteria tersebut peneliti dapatkan dengan berdasarkan pada karakteristik anak dengan conduct disorder di DSM IV. Peneliti merumuskan ciri-ciri anak dengan conduct disorder ke dalam lembar observasi (untuk mengamati perilaku anak di sekolah) dan panduan wawancara bagi orangtua dan guru. Responden penelitian di tengah-tengah pelaksanaan penelitian berkurang satu karena tidak 
bersedia mengikuti pelatihan. Dengan demikian, hingga akhir penelitian responden hanya berjumlah dua orang saja.

\section{Metode Pendekatan Masalah}

Penelitian ini menggunakan pelatihan sebagai salah satu bentuk pendekatan triangulasi. Menurut Patton (1990), salah satu metode dalam triangulasi adalah dengan Pure Qualitative Strategy yang meliputi naturalistic inquiry, data kualitatif serta content analysis sebagai metode pembahasannya. Dalam metode ini sebelum program dilakukan (dalam hal ini pelatihan "Sahabatku Bintang") terlebih dahulu terdapat pengambilan data untuk mengetahui kondisi yang dialami oleh responden. Selanjutnya, disusunlah sebuah program yang melibatkan responden dan dilihat bagaimana proses yang dialami responden selama program berlangsung. Sesudah program selesai dilaksanakan, wawancara dilakukan untuk mengetahui sejauh mana pemahaman dan aplikasi responden setelah program tersebut. Selanjutnya, data tersebut dianalisis untuk memperdalam pemahaman peneliti terhadap perilaku responden.

Pelatihan "Sahabatku Bintang" ini tidak bertujuan untuk mengetahui sejauh mana efektivitas dari pelatihan tersebut. Pelatihan ini bertujuan untuk dapat lebih memahami proses yang terjadi selama pelatihan berlangsung dan proses perubahan yang terjadi sesudah pelatihan.

\section{Metode Pengumpulan Data}

Penelitian ini dilakukan dengan menggunakan wawancara semi terstruktur dan observasi semi sitematik. Berikut ini adalah metode pengumpulan data oleh peneliti:

Tabel 1. Pengambilan Data

\begin{tabular}{|c|c|c|}
\hline No. & Metode Pengambilan Data & Alat Pengambilan Data \\
\hline 1 & Wawancara dengan Guru & $\begin{array}{l}\text { Pedoman Wawancara } \\
\text { semi terstruktur }\end{array}$ \\
\hline 2 & Wawancara dengan Orang tua & $\begin{array}{l}\text { Pedoman Wawancara } \\
\text { semi terstruktur }\end{array}$ \\
\hline 3 & Observasi di Sekolah & $\begin{array}{l}\text { Observasi semi } \\
\text { sistematik }\end{array}$ \\
\hline 4 & $\begin{array}{l}\text { Penempatan Responden } \\
\text { Penelitian }\end{array}$ & $\begin{array}{l}\text { Analisis data temuan } \\
\text { dengan DSM IV }\end{array}$ \\
\hline 5 & $\begin{array}{l}\text { Penelitian "Sahabatku } \\
\text { Bintang" }\end{array}$ & $\begin{array}{l}\text { Observasi semi } \\
\text { sistematik }\end{array}$ \\
\hline 6 & Wawancara dengan anak & $\begin{array}{l}\text { Pedoman Wawancara } \\
\text { semi terstruktur }\end{array}$ \\
\hline 7 & Wawancara dengan Guru & $\begin{array}{l}\text { Pedoman Wawancara } \\
\text { semi terstruktur }\end{array}$ \\
\hline 8 & Wawancara dengan Orang tua & $\begin{array}{l}\text { Pedoman Wawancara } \\
\text { semi terstruktur }\end{array}$ \\
\hline
\end{tabular}

\section{Prosedur Intervensi:}

Modul Pelatihan "Sahabatku Bintang”

Modul pelatihan ini, disusun berdasarkan aspek dari perilaku memaafkan yakni pemahaman emosi pada diri sendiri ataupun orang lain, empati, pemahaman akan alternatif penyelesaian konflik, serta pemahaman akan kelebihan dari perilaku memaafkan (Enright, 2001).

Metode ini banyak menggunakan permainan dan interaksi aktif. Menurut Poerwandari (1998), metode permainan dapat digunakan untuk mengambil data dalam penelitian kualitatif. Terlebih lagi, apabila responden penelitian adalah anakanak.

Dari semua aspek tersebut, maka peneliti merumuskan tahapan-tahapan dari pelatihan yang akan diberikan kepada responden sebagai berikut:

1. Tahap I ("Pahami Emosiku")

Pada tahapan ini, pelatihan dilakukan untuk mengajak anak memahami emosi-emosi yang mereka rasakan, baik emosi negatif maupun positif. 
2. Tahap II ("Empati untuk Semua") Di dalam tahapan ini, anak mulai difasilitasi untuk menunjukkan sejauh mana sikap empati yang mereka miliki terhadap orang lain.

3. Tahap III ("Berdamai Yuk!") Setelah diminta untuk mengembangkan pemahaman tentang emosi mereka sendiri dan empati bagi orang lain, anak-anak diminta untuk mengembangkan resolusi konflik.

4. Tahap IV ("Memaafkan: Untukku dan Untukmu")

Pelatihan ini ditutup dengan mengembangkan ketrampilan anak untuk mengatasi konflik dengan cara memaafkan.

\section{Teknik Analisis Data}

Analisis data akan menggunakan metode kualitatif successive approximation (Neuman, 2000). Metode ini sejalan dengan tahapan penelitiah yang hendak dilakukan. Analisis data dengan metode ini terdiri dari:

1. Sort and Classify adalah upaya awal untuk mengklasifikasikan data yang masih mentah

2. Open Coding. Pada tahapan ini data mulai dikelompokkan dalam tema-tema besar

3. Axial Coding. Data mulai diorganisasikan ke dalam tema dan dalam konsep-konsep inti yang terkait dengan penelitian.

4. Selective Coding. Peneliti mulai membuat perbandingan antar data yang ditemukan dan ditunjang pula oleh konsep teoretis yang telah tersusun dengan baik. Dengan demikian akan dapat dilakukan analisis dengan generalisasi dalam berbagai tema pokok yang hendak diangkat.

5. Interpretasi dan Elaborasi. Peneliti mulai menggabungkan berbagai temuan yang didapat sehingga pada akhirnya dapat membuat hasil dan kesimpulan dan data di lapangan.

Untuk memudahkan membaca data penelitian, maka setiap hasil temuan disertai dengan kutipan-kutipan dari responden. Kutipan-kutipan ini berasal dari wawancara, observasi dan catatan lapangan. Di akhir kutipan dicantumkan nama responden dan darimana data diambil. Kode angka di bagian paling akhir, menunjukkan letak data tersebut dalam penulisan verbatim.

Tabel 2. Keterangan Kode Klasifikasi Data

\begin{tabular}{ll}
\hline Kode & Keterangan \\
\hline WK & Wawancara dengan responden Koko \\
WOTK & Wawancara dengan orangtua Koko \\
WGK & Wawancara dengan guru Koko \\
OK & Observasi dengan Koko \\
WA & Wawancara dengan responden Anto \\
WOTA & Wawancara dengan orangtua Anto \\
WGA & Wawancara dengan guru Anto \\
OA & Observasi dengan Anto \\
CL & Catatan Lapangan \\
\hline
\end{tabular}




\section{HASIL PENELITIAN}

Berikut ini adalah deskripsi conduct disorder pada diri anak melalui hasil wawancara pada penelitian awal dan sesudah pelatihan berlangsung. Wawancara dan observasi dilakukan setelah satu minggu pelatihan dan berlangsung selama satu kali.

\section{Tabel 3. Identifikasi Conduct Disorder pada Responden Koko}

\begin{tabular}{|c|c|c|}
\hline Sebelum Pelatihan & Jenis Perilaku & Sesudah Pelatihan \\
\hline $\begin{array}{l}\text { Mendorong teman } \\
\text { perempuan, mengganggu } \\
\text { teman saat sedang } \\
\text { menulis, mencolek pipi } \\
\text { teman dengan kapur }\end{array}$ & $\begin{array}{l}\text { Melakukan } \\
\text { intimidasi } \\
\text { terhadap teman }\end{array}$ & $\begin{array}{l}\text { Melakukan ancaman } \\
\text { terhadap teman }\end{array}$ \\
\hline $\begin{array}{l}\text { Mendorong teman } \\
\text { sambil menantang } \\
\text { berkelahi }\end{array}$ & $\begin{array}{l}\text { Memulai } \\
\text { perkelahian } \\
\text { dengan teman }\end{array}$ & $\begin{array}{l}\text { Menantang teman } \\
\text { berkelahi dan } \\
\text { akhirnya saling } \\
\text { memukul (O.K. 06) }\end{array}$ \\
\hline $\begin{array}{l}\text { Memuknाराग teman, } \\
\text { mencubit, } \\
\text { menusuk tengkuk } \\
\text { teman dengan } \\
\text { penggaris }\end{array}$ & $\begin{array}{l}\text { Wबागतशरा!! } \\
\text { Menyakiti } \\
\text { teman } \\
\text { secara fisik }\end{array}$ & $\begin{array}{l}\text { Menggigit teman, } \\
\text { menyenggol teman } \\
\text { perempuan dengan } \\
\text { tiang bendera hingga } \\
\text { menangis (O.K.06) }\end{array}$ \\
\hline $\begin{array}{l}\text { Mengambil penggaris milik } \\
\text { teman, mengambil mainan } \\
\text { milik saudara sepupu, } \\
\text { mengambil buku milik } \\
\text { perpustakaan }\end{array}$ & $\begin{array}{l}\text { Mengambil } \\
\text { barang milik } \\
\text { orang lain }\end{array}$ & $\begin{array}{l}\text { Mengambil botol } \\
\text { milik teman dan } \\
\text { membuangnya di } \\
\text { tempat sampah } \\
\text { (O.K.06) }\end{array}$ \\
\hline $\begin{array}{l}\text { Mengambil uang milik kakak } \\
\text { dan ibu untuk bermain } \\
\text { playstation, mengambil uang } \\
\text { untuk membayar iuran sekolah }\end{array}$ & $\begin{array}{l}\text { Mengambil } \\
\text { uang milik } \\
\text { orang lain }\end{array}$ & $\begin{array}{l}\text { Tidak ditemukan } \\
\text { Tidak ditemukan }\end{array}$ \\
\hline $\begin{array}{l}\text { Melempar teman dengan } \\
\text { memakai sabit, melindas kaki } \\
\text { teman dengan sepeda }\end{array}$ & $\begin{array}{l}\text { Menyakiti orang } \\
\text { lain dengan } \\
\text { menggunakan } \\
\text { senjata }\end{array}$ & Tidak ditemukan \\
\hline Mengatai temannya "monyet!" & $\begin{array}{l}\text { Mengumpat } \\
\text { terhadap orang } \\
\text { lain }\end{array}$ & $\begin{array}{l}\text { Mengatai temannya } \\
\text { "Ngisruh!" }\end{array}$ \\
\hline $\begin{array}{l}\text { Jalan-jalan ketika berada di } \\
\text { kelas, tidak mengerjakan tugas } \\
\text { yang diberikan oleh guru, } \\
\text { ramai ketika guru tengah } \\
\text { menjelaskan, mengganggu } \\
\text { teman di kelas }\end{array}$ & $\begin{array}{l}\text { Melanggar } \\
\text { peraturan di } \\
\text { sekolah }\end{array}$ & $\begin{array}{l}\text { Jalan-jalan ketika } \\
\text { berada di kelas, } \\
\text { mengerjakan tugas } \\
\text { yang diberikan oleh } \\
\text { guru namun tidak } \\
\text { selesai, ramai ketika } \\
\text { guru tengah } \\
\text { menjelaskan, } \\
\text { mengganggu teman } \\
\text { di kelas (O.K 05-06) }\end{array}$ \\
\hline
\end{tabular}

Tabel 4. Identifikasi Conduct Disorder pada Responden Anto

\begin{tabular}{|c|c|c|}
\hline Sebelum Pelatihan & Jenis Perilaku & Sesudah Pelatihan \\
\hline $\begin{array}{l}\text { Meminta uang dan } \\
\text { makanan kepada } \\
\text { teman, merebut } \\
\text { makanan milik teman }\end{array}$ & $\begin{array}{l}\text { Melakukan } \\
\text { intimidasi } \\
\text { terhadap teman }\end{array}$ & Tidak ditemukan \\
\hline Tidak ditemukan & $\begin{array}{l}\text { Memulai } \\
\text { perkelahian } \\
\text { dengan teman }\end{array}$ & Tidak ditemukan \\
\hline $\begin{array}{l}\text { Memukul kepala teman } \\
\text { perempuan dari belakang, } \\
\text { menendang dan } \\
\text { menampar teman }\end{array}$ & 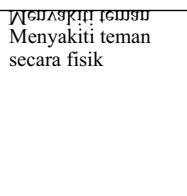 & $\begin{array}{l}\text { Memukul dan mencakar } \\
\text { teman yang } \\
\text { mentertawakannya } \\
\text { (O.A.06). memukul dan } \\
\text { menendang } \\
\text { teman (W.G.A 02: 1195- } \\
\text { 1198) }\end{array}$ \\
\hline $\begin{array}{l}\text { Mengambil spidol dan } \\
\text { buku dari tas teman } \\
\text { tanpa izin }\end{array}$ & $\begin{array}{l}\text { Mengambil barang } \\
\text { milik orang lain }\end{array}$ & $\begin{array}{l}\text { Mengambil buku milik } \\
\text { teman (O.A.06) }\end{array}$ \\
\hline Tidak ditemukan & $\begin{array}{l}\text { Mengambil uang } \\
\text { milik orang lain }\end{array}$ & Tidak ditemukan \\
\hline $\begin{array}{l}\text { Menusuk teman dengan } \\
\text { menggunakan bolpoin } \\
\text { pada bagian punggung }\end{array}$ & $\begin{array}{l}\text { Menyakiti orang } \\
\text { lain dengan } \\
\text { menggunakan } \\
\text { senjata }\end{array}$ & Tidak ditemukan \\
\hline $\begin{array}{l}\text { Berkata "asu, bajingan!" } \\
\text { kepada teman }\end{array}$ & $\begin{array}{l}\text { Mengumpat } \\
\text { terhadap } \\
\text { orang lain }\end{array}$ & Tidak ditemukan \\
\hline $\begin{array}{l}\text { Jalan-jalan ketika } \\
\text { di kelas, tidak } \\
\text { mengerjakan tugas } \\
\text { yang diberikan } \\
\text { guru, ramai ketika } \\
\text { guru menjelaskan, } \\
\text { mengganggu teman } \\
\text { di kelas, tidak membawa } \\
\text { pekerjaan rumah yang } \\
\text { diperintahkan oleh guru, } \\
\text { menggebrak meja } \\
\text { ketika diperingatkan } \\
\text { oleh guru }\end{array}$ & 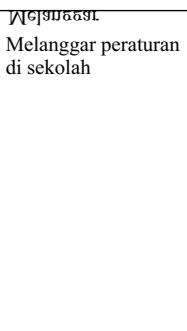 & $\begin{array}{l}\text { Jalan-jalan ketika di kelas, } \\
\text { ramai ketika guru tengah } \\
\text { menjelaskan (O.A.06) }\end{array}$ \\
\hline
\end{tabular}

\section{PEMBAHASAN}

Ada beberapa perbedaan latar belakang keluarga antara Koko dan Anto. Namun, terdapat pula kesamaan antara keduanya. Latar belakang keluarga yang menonjol adalah adanya pola hukuman yang dilakukan oleh orangtua terhadap anak. Kedua anak sama-sama mengalami hukuman fisik dari orang tua misalnya memukul ataupun menjewer telinga. 
Walaupun pada orang tua Koko hal tersebut sudah tidak dilakukan lagi, namun hukuman fisik masih seringkali menjadi ancaman agar anak mau menuruti orangtua. Lingkungan sosiokultural juga memungkinkan anak untuk mengadaptasi perilaku-perilaku maladaptif yakni perkelahian antar teman menjadi bagian dalam keseharian anak.

Menurut Snyder dan Patterson (Dodge \& Pettit, 2003), ada pola hubungan antar orangtua dan anak yang berpotensi menyebabkan anak mengalami conduct disorder. Pola tersebut adalah adanya inkonsistensi dalam menerapkan disiplin bagi anak. Jika orangtua telah mulai memberikan nasihat atau peringatan namun reaksi anak bersifat aversif (misalnya berteriak atau temper tantrum), orangtua kemudian mengalah dan mendiamkan anak sampai reaksinya berkurang. Pada akhirnya transfer nilai menjadi terhambat sebab anak mulai paham kalau pola aversif yang ia kembangkan adalah "senjata" baginya. Efektivitas dari hukuman fisik juga dipertanyakan. Hal ini disebabkan seringkali anak tidak menerima penjelasan lebih lanjut mengapa perbuatan tersebut dilarang oleh orang tua. Melainkan, anak langsung dihukum dan harus menerima begitu saja. Ancaman kemudian menjadi andalan bagi orangtua untuk dapat mengontrol perilaku anak.

Pada kasus Koko dan Anto hal tersebut juga terjadi. Oleh sebab itu, transfer nilai yang diharapkan dapat terlaksana dengan baik menjadi terhambat. Ketika orangtua dan guru dapat menyampaikan nasehat maupun peringatan kepada anak, situasi yang terjadi sangat tidak mendukung. Anak lebih cenderung melampiaskan kemarahan melalui cara-cara destruktif, seperti mengamuk di kamar maupun menggebrak meja di sekolah. Selain itu, jika orangtua dan guru sudah merasa kewalahan mereka cenderung akan mendiamkan anak. Pengertian anak terhadap perilaku yang adapatif dan maladaptif menjadi rancu. Mereka merasa bahwa apa yang mereka lakukan saat melampiaskan rasa marah sudah mewakili apa yang mereka inginkan. Padahal cara yang mereka lakukan lebih condong ke arah destruktif dan agresif terhadap orang lain.

Proses yang dialami oleh responden selama pelatihan berlangsung menunjukkan suatu hal yang menarik untuk dikaji. Kedua responden tergolong anak yang tidak patuh terhadap peraturan khususnya selama berada di kelas. Akan tetapi, dalam pelaksanaan pelatihan mereka menunjukkan sikap kooperatif dan mau melakukan apa yang diinstruksikan oleh fasilitator dari awal sampai akhir. Berdasarkan pendapat dari Erikson (Monks, Knoers, \& Haditono, 2001) diketahui bahwa anak-anak pada usia sekolah dasar cenderung mengembangkan industry vs inferiority. Harga diri anak dapat dikembangkan melalui kerja keras dan penghargaan atas apa yang pernah mereka lakukan. Oleh sebab itu, adanya penghargaan (berupa reward dan pujian) yang diberikan selama proses pelatihan berlangsung memungkinkan adanya reaksi positif dari kedua responden.

Pada saat pelatihan berlangsung, responden Anto lambat laun mulai bersedia 
bercerita tentang pengalaman emosi yang dirasakannya. Di sisi lain, responden Koko tampak mengalami kesulitan untuk mengungkapkan emosi apa yang ia rasakan. Ia seringkali melontarkan jawaban yang sama dengan Anto, namun tidak memberikan alasan yang tepat atau bahkan mengganti jawaban. Menurut Koustik dan Fouts (2003), anak memiliki pola identifikasi yang lekat dengan significant other. Apabila orangtua sebagai salah satu significant other tidak dapat memberikan pola identifikasi emosi yang adekuat, maka anak akan cenderung menirunya. Terlebih lagi, jika terdapat kekerasan yang dilakukan baik sesama orangtua maupun orangtua terhadap anak. Padahal dalam mengembangkan perilaku memaafkan dasar yang harus dicapai adalah kemampuan untuk identifikasi emosi terutama pada emosi marah.

Selanjutnya, kemampuan anak untuk dapat melakukan empati dapat semakin mengembangkan kemampuannya dalam memaafkan. Pemahaman terhadap empati mereka kontraposisikan dengan apa yang mereka rasakan. Anak beranggapan bahwa mereka melakukan perilaku destruktif karena telah disakiti lebih dahulu. Padahal pembalasan yang mereka lakukan biasanya lebih menyakiti orang lain daripada apa yang mereka terima. Selain itu, mereka juga cenderung memiliki kontrol diri yang rendah sehingga tidak terdapat tenggat waktu antara perlakuan teman dengan balasan yang mereka berikan. Hal tersebut tidaklah berdiri sendiri melainkan bentukan dari sistem yang ada baik dari keluarga, maupun lingkungan sosiokultural lainnya. Walaupun demikian, dalam pelatihan, ketika merasa senang karena berhasil menang Anto bersedia membagi makanan miliknya dengan Koko. Hal ini dapat dilihat, bahwa sebenarnya potensi empati anak masih dapat dikembangkan.

Perilaku memaafkan dalam pelatihan yang dipersepsi oleh para responden adalah pembalasan yang setimpal atas perbuatan teman tersebut. Hal ini senada dengan perilaku memaafkan dilihat dari perkembangan anak. Menurut Enright dan Huang (2000), ciri yang mendasari perilaku memaafkan pada anak adalah apabila mereka telah mendapatkan hak mereka kembali, yakni dengan cara membalas perbuatan orang lain. Selain itu, mereka dapat memaafkan perbuatan orang lain apabila terdapat tekanan berupa perasaan bersalah jika mereka tidak melakukannya. Begitu pula menurut penjelasan Piaget (Santrock, 1999) bahwa anak yang tengah berada dalam transisi tahapan egosentrisme dan realisme memiliki pandangan yang berbeda dengan orang dewasa. Mereka cenderung memandang perbuatan yang dilakukan oleh seseorang hendaklah mendapat balasan secara langsung tanpa melihat konteks maupun situasi dan kondisi pada saat itu.

Perubahan perilaku pascapelatihan tampak muncul di responden Anto. Responden Anto menyatakan bahwa ia mendapatkan pengetahuan tentang perilaku memaafkan selama pelatihan langsung. Akan tetapi, aplikasinya dalam kehidupan sehari-hari terutama ketika berada di sekolah tidak selalu ia lakukan. Jika memang merasa marah, maka ia benar-benar 
akan membalas perbuatan teman tersebut. Namun demikian, Anto juga menunjukkan sikap empati pada temannya. Ketika ada teman laki-lakinya yang menangis, ia mendekati dan bertanya mengapa temannya tersebut menangis. Perilaku lain yang juga muncul adalah kemauannya untuk lebih mematuhi peraturan sekolah, misalnya mau menulis dan mengerjakan tugas di sekolah. Hal ini disinyalir karena guru juga bersedia untuk berpartisipasi. Sesudah pelatihan berlangsung, guru meminta saran untuk menghadapi anak tersebut. Hasil yang tampak adalah penurunan intonasi guru ketika menasehati Anto, bahkan guru bersedia membimbing anak secara langsung saat istirahat. Hal ini berkontribusi positif pada responden Anto, sebab sedikit demi sedikit ada perhatian yang ia dapatkan di sekolah. Sedangkan reaksi dari orangtua pascapelatihan tidak berhasil peneliti dapat, sebab orangtua Anto menolak untuk diwawancarai atau mengisi angket seputar perilakuAnto.

Perubahan perilaku responden Koko belum terlalu nampak. Hal ini terkait dengan aspek intrapsikis maupun interpersonal. Pola asuh keluarga yang bersifat ambigu, yakni Koko mendapatkan apa yang ia inginkan namun juga mendapat hukuman fisik jika dianggap "nakal”, mempengaruhi hubungan interpersonal dengan temannya. Koko lebih berinisiatif untuk mengganggu teman sebayanya. Orangtua Koko juga mengaku heran sebab Koko dapat bersikap kooperatif selama pelatihan berlangsung. Peneliti kemudian berbagai informasi pendekatan yang dilakukan kepada anak. Namun demikian, sayangnya peneliti tidak melakukan konfirmasi lebih lanjut apakah orangtua juga mengikuti pendekatan yang sama. Guru Koko lebih cenderung bersikap apriori ketika peneliti menjelaskan pendekatan yang digunakan selama pelatihan. Guru tersebut menyatakan kalau Koko bersikap kooperatif karena belum kenal terlalu dekat dengan peneliti dan rekan-rekan yang lain. 
Berikut ini adalah gambar rangkuman dari dinamika yang terjadi pada diri responden secara menyeluruh:

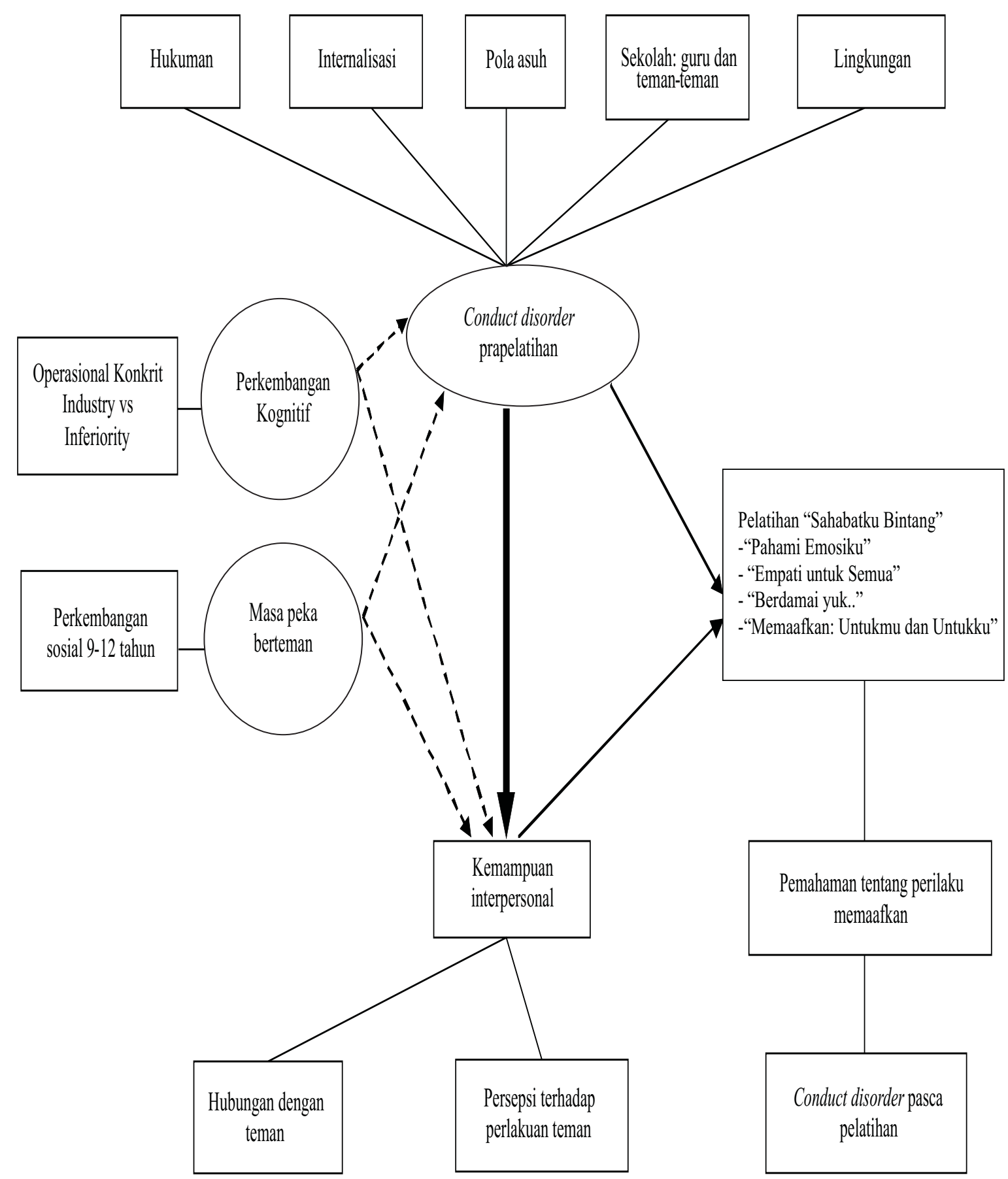

Gambar 1. Dinamika Temuan Penelitian 


\section{SIMPULAN}

Perilaku memaafkan pada anak dengan conduct disorder dipengaruhi oleh dimensi intrapsikis maupun interpersonal. Dimensi intrapsikis meliputi aspek kognitif dan emosi sedangkan dimensi interpersonal meliputi hubungan pertemanan anak. Aspek kognitif dan emosi ditunjukkan melalui persepsi responden terhadap perlakuan teman pada dirinya. Responden juga memaafkan teman apabila mereka telah dapat melakukan pembalasan yang bersifat destruktif. Hal tersebut sesuai dengan tingkat perkembangan responden dan pemahamannya akan perilaku memaafkan.

Pelatihan "Sahabatku Bintang" dapat menjadi salah satu alternatif dalam upaya penanganan anak dengan conduct disorder. Selama pelatihan berlangsung, anak menunjukkan sikap yang adapatif serta mau menuruti instruksi sejak awal sampai akhir. Sikap positif dan penghargaan yang diberikan oleh fasilitator maupun peneliti kepada para responden ditanggapi dengan perilaku yang positif pula. Metode yang dipergunakan selama pelatihan berlangsung dapat membantu responden untuk dapat memahami materi.

Perubahan yang terjadi selama pelatihan berlangsung dan sesudahnya, lebih pada kemampuan dan keterbukaan responden untuk memahami serta merasakan kembali pengalamannya. Perubahan pada tiap responden tidaklah sama satu sama lain. Hal tersebut didukung pula oleh kemampuan tiap responden untuk mengembangkan jalinan pertemanan dengan orang lain. Perubahan perilaku anak juga ditunjang oleh penerimaan dari lingkungan terutama teman sebaya. Guru dan orangtua juga memiliki peranan penting dalam proses perubahan tersebut, yakni dalam membantu anak mengembangkan perilaku adaptifnya.

\section{DAFTAR PUSTAKA}

Agnew, C.R, Van Lange, P.A.M, Rusbult, C.E. \& Lanston, C.A.(1998). Cognitive Interdependence: Commitment anda The Mental Representation of Close Relationships. Journal of Personality and Social Psychology.74 (4), 939-954.

Belsky, J.(1991). Infancy, Child and Adolescence. Boston: Allyn\&Bacon

Collin, W. A. \& Laursen, B. (1992). Conflict and Relationship during Adolescence. Dalam Shantz dan Santrup (editor). Conflict in Child and Adolescence. Cambridge: Cambridge University Press.

Denzin, N. K, Lincoln, Y.S (ed.). (1994). Handbook of Qualitative Research. London: Sage Publication.

Dodge, K. A, Pettit, G. S. (2003). A Biopsychosocial Model of The Development of Chronic Conduct Problems in Adolescence. Journal of Developmental Psychology. 39 (2), 349-371.

Enright, R. D. (2001). Forgiveness as $A$ Choice: A Step-by-Step Process for Resolving Anger and Restoring Hope. Washington DC: APA Life Tools.

Fisher, J. (2000). Mengelola Konflik: Ketrampilan dan Strategi untuk Bertindak. Penyunting: Kartikasari, S. N. Jakarta: The British Council.

Hastings, P. D, Zahn-Waxler, C., Usher, B., Robinson, J. A., Bridges, D. (2000). The Development of Concern for 
Others in Children with Behavior Problems. Journal of Developmental Psychology.36 (5), 531-546.

Hetherington, E. M., Parke, B. D, Locke, V. O. (1999). Child Psychology: A Contemporary Viewpoint. $5^{\text {th }}$ Ed. Boston: McGraw-Hill College.

Huang, S.T \& Enright, R. D. (2000). Forgiveness and Anger-Related Emotions in Taiwan: Implications for Therapy. Psychotherapy.37 (1), 71-79.

Karremans, J. C., Van Lange, P. A. M., Ouwerk, J. W. \& Kluwer, E. S. (2003). When Forgiving Enhances Psychological Well-being: The Role of Interpersonal Commitment. Journal of Personality and Social Psychology. $84(5), 1011-1026$.

Kostiuk, L. M., Fouts, G. T. (2002). Understanding of Emotions and Emotion Regulation in Adolescent Females with Conduct Problems: A Qualitative Analysis. The Quality Report. 7 (1).

Mc. Cullough, M. E., Worthington Jr, E. L, Rachal, K. C. (1997). Interpersonal Forgiving in Close Relationship. Journal of Personality and Social Psychology.76(2), 321-336.

Mc. Cullough, M. E., Worthington Jr, E. L, Rachal, K. C., Sandage, S. J, Brown, S. W., High, T. L. (1998). Interpersonal Forgiving in Close Relationship II: Theoretical Elaboration and Measurement. Journal of Personality and Social Psychology. 75 (6), 15861603.

Monks, F. J, Knoers, A. M. P., Haditono, S. R. (2001). Psikologi Perkembangan. Yogyakarta: Gadjah Mada University Press.

Moleong, L. J. (2002). Metodologi Penelitian Kualitatif. Bandung:
Rosdakarya.

Neuman, L. W. (2000). Social Research Methods: Qualitative and Quantitative Approaches. $4^{\text {th }}$ Ed. Boston: Allyn\&Bacon.

Poerwandari, E. K. (1998). Pendekatan Kualitatif dalam Penelitian Psikologi. Jakarta: Lembaga Pengembangan Sarana Pengukuran dan Pendidikan Psikologi (LPSP3) Universitas Indonesia.

Patton, M. Q. (1991). Qualitative Evaluation and Research Methods. $2^{\text {nd }}$ Ed. Newburry Park: Sage Publications.

Rusbult, C. E., Verette, J., Whitney, G. A, Slovik, L. F., Lipkus, I. (1991). Accommodation Processes in Close Relationships: Theory and Preliminary Empirical Evidence. Journal of Personality and Social Psychology. 60 (1), 3-78.

Santrock, J. W. (1999). Life-Span Development. $7^{\text {th }}$ Ed. Boston: Allyn\&Bacon.

Stormshak, E. A \& Webster-Stratton, J. (1999). The Qualitative Interaction of Children with Conduct Problems and Their Peers: Differential Correlates with Self-Report Measures, Home Behavior and School Behavior Problems. Journal of Applied Developmental Psychology. 20 (2), 295-317.

Wenar, C. (1994). Developmental Psychopathology: From Infancy through Adolescence. $3^{\text {rd }}$ Ed. New York: McGraw-Hill Company.

Zechmeister, J. S. \& Romero, C. (2002). Victim and Offender Accounts of Interpersonal Conflict: Autobiographical Narratives of Forgiveness and Unforgiveness. Journal of Personality and Social Psychology. 82 (4), 675-686. 
